\title{
Öğrencilerin Okudukları Bölümlerinden Duydukları Memnuniyeti Etkileyen Faktörlerin Sıralı Lojistik Regresyon Analizi ile Belirlenmesi
}

\section{Determination of Factors Affecting Students' Satisfaction with The Departments They Study by Ordinal Logistic Regression Analysis}

\author{
Veli Rıza Kalfa a , Engin Çakır ${ }^{b, *}$ \\ ${ }^{a}$ Öğr. Gör. Dr., Pamukkale Üniversitesi, Honaz Meslek Yüksekokulu, Finans-Bankacılık ve Sigortacılık Bölümü, 20330, Honaz/Denizli/Türkiye. \\ ORCID: 0000-0002-8100-7786
}

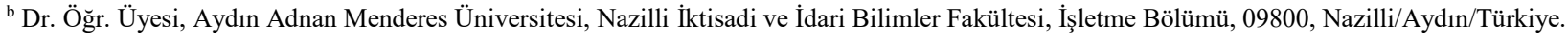
ORCID: 0000-0002-5906-4178

\begin{tabular}{l} 
MAKALE BİLGİSİ \\
Makale Geçmişi: \\
Başvuru tarihi: 08 Ocak 2020 \\
Düzeltme tarihi: 23 Nisan 2020 \\
Kabul tarihi: 29 Nisan 2020 \\
\hline Anahtar Kelimeler: \\
Cinsiyet \\
Öğrenci Memnuniyeti \\
Sınıf \\
Sıralı Lojistik Regresyon
\end{tabular}

\section{A R T I C L E IN F O}

\section{Article history:}

Received 08 January 2020

Received in revised form 23 April 2020

Accepted 29 April 2020

\section{Keywords:}

Gender

Student Satisfaction

Class

Ordinal Logistic Regression
ÖZ

$\mathrm{Bu}$ çalışmanın amacı, öğrencilerin bölümlerine olan memnuniyetlerini etkileyen değişkenleri, sıralı lojistik regresyon analizi ile belirlemektir. Bağımlı ve bağımsız değişken ayrımının yapılarak bağımsız değişkenlerin bağımlı değişken üzerindeki etkisi incelenmeye çalışıldığından dolayı çalıșma genel tarama modelleri arasından ilișkisel tarama modeli seçilerek yapılmıștır. Çalıșmanın kapsamını Aydın Adnan Menderes Üniversitesi Nazilli İktisadi ve İdari Bilimler Fakültesinin farklı bölümlerinde okuyan 676 öğrenci oluşturmaktadır. Çalıșmada veri toplama araçlarından biri olan anket tekniğinden faydalanılmış ve hazırlanan anketler öğrencilere online olarak uygulanmıştır. Çalışmada sıralı lojistik regresyon analizi kullanılmış ve buna göre cinsiyet ve sınıf değişkenlerinin, bağımlı değişken üzerinde istatistiksel olarak anlamlı bir etki oluşturduğu, kız öğrencilerin erkek ögrencilere göre bölümlerinden daha fazla memnun oldukları sonucuna ulaşılmıştır. Ayrıca öğrencilerde sınıf ilerlemesinin bölümlerinden memnuniyetlerinde azalma oluşturduğu sonucuna da varılmıştır.

\section{A B S T R AC T}

The aim of this study is to determine the variables that affect students' satisfaction with their departments by using ordinal logistic regression analysis. Since the effect of independent variables on the dependent variable is examined by making the distinction between the dependent and independent variables, the study was conducted by choosing a relational screening model among the general screening models. The scope of the study consists of 676 students studying at different departments of the Faculty of Economics and Administrative Sciences at Nazilli Adnan Menderes University. In the study, the survey method, one of the data collection methods, was used and the prepared surveys were applied to the students online. Ordinal logistic regression analysis used in the study and accordingly, it was concluded that gender and class variables had a statistically significant effect on the dependent variable and that female students were more satisfied with their departments than male students. In addition, as the class progressed, it was concluded that the students' satisfaction with their departments decreased.

\section{Giriş}

Eğitim sektörü son yıllarda tüm dünyada çok hızlı büyümekte, küreselleşme ve dijital devrim, eğitimde yeni ve çeşitli disiplinlere talep yaratmaktadır. Eğitim sağlama maliyeti, dünya genelinde artan enflasyonla birlikte daha iyi öğretim metodolojileri ve öğrenme araçları nedeniyle artmıştır. Yükseköğretimdeki kurum sayısındaki hızlı artış, yoğun bir rekabete yol açmıştır (Isani ve Virk, 2005). Teknoloji ve küreselleşme alanındaki gelişmeler sayesinde öğrenciler kolayca ve anında bilgiye ulaşabilirler. Bu rekabetçi ortamda, sadece öğrencilerine kaliteli eğitim ve

\footnotetext{
* Sorumlu yazar/Corresponding author.

e-posta: engincakir@adu.edu.tr
} 
yapıcı bir ortam sağlayan kurumlar mükemmel olabilmektedir, çünkü bu faktörler öğrencilerin kurumlara başvuru yapmaları sırasında aldıkları kararları etkileyebilmektedir (Butt ve Rehman, 2010).

Üniversiteler potansiyel olarak bölgesel ekonomik kalkınmaya çeşitli şekillerde katkıda bulunurlar: Araştırma, öğretim yoluyla insan sermayesi oluşturma, teknoloji geliştirme ve aktarma ve uygun ortamın çoğaltılması. Üniversite çıktıları ile bölgesel kalkınma etkileri arasındaki ilişkiler Şekil 1'de verilmiştir (Goldstein ve Renault, 2004). Üniversiteler beşerî sermaye üreticileridir. Literatür, ülke düzeyinde beşerî sermayenin kalkınma ve büyüme için önemli olduğunu ortaya koymaktadır. Üniversite büyüklüğü ile, kişi başına GSYİH arasında güçlü bir ilişki bulunmaktadır (Bir bölgedeki üniversite sayısında \%10'luk bir artış, kişi başına GSYİH'da yaklaşık olarak \%0,4'lük bir artışa neden olmaktadır). Bir başka ifade ile, kişi başına GSYİH ve üniversite varlığı ilişkisi, kısmen beşerî sermaye arzını ve yeniliği artırmaktadır (Valero ve Reenen, 2019).

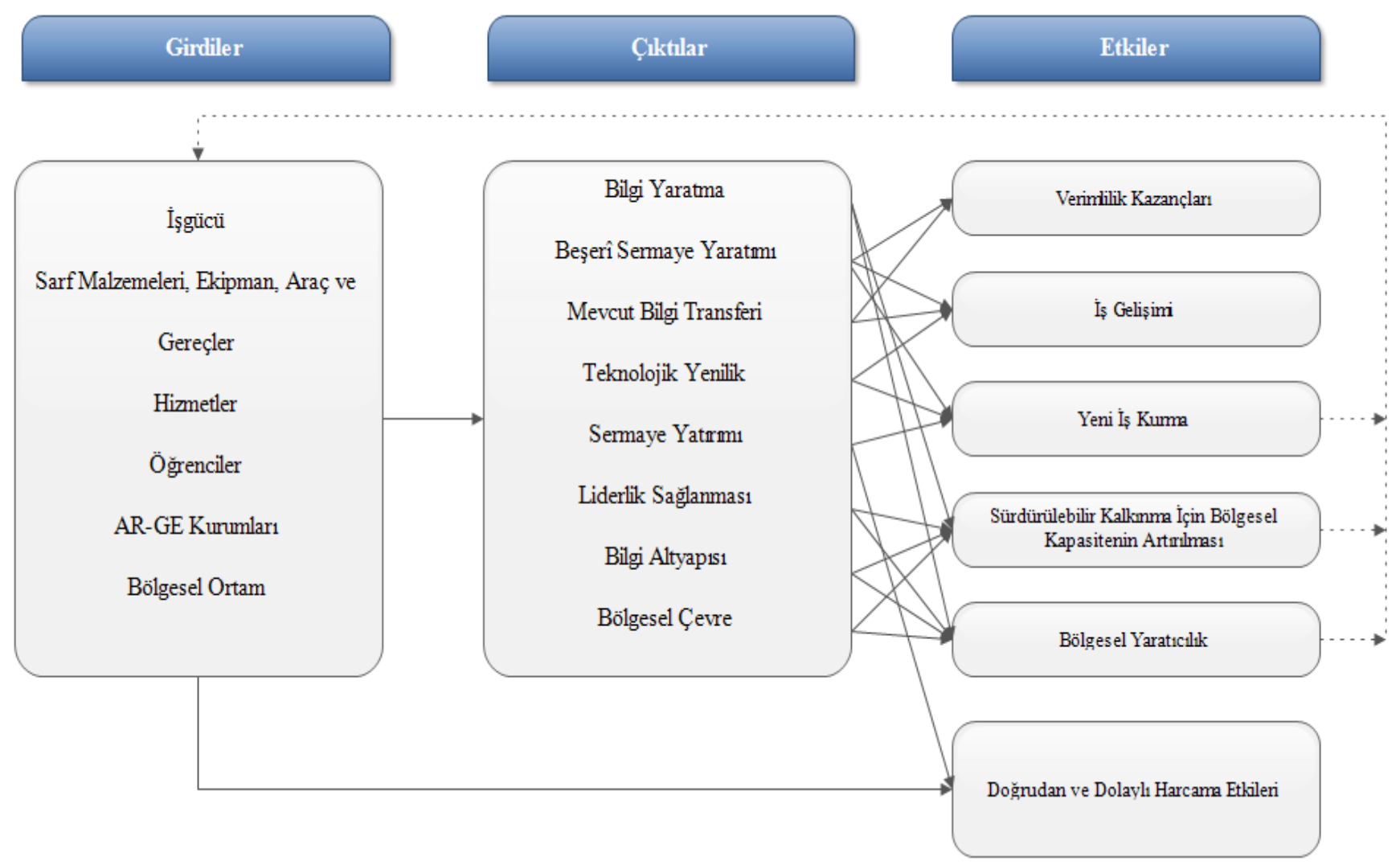

Şekil 1. Üniversite Çıktıları ve Beklenen Ekonomik Etkiler

Kaynak: (Goldstein ve Renault, 2004)

Üniversiteler, öğrencilerin ihtiyaçlarını ve beklentilerini belirleyerek ve karşılayarak üstün yetenekli öğrencileri en iyi şekilde kendilerine çekebilir ve ellerinde tutabilirler. $\mathrm{Bu}$ amaçla, üniversitelerin öğrenciler için neyin önemli olduğunu tespit etmesi ve sunması gerekmektedir (Elliot ve Shin, 2002; Schertzer ve Schertzer, 2004). Üniversiteler hem ulusal hem de uluslararası düzeyde entelektüel sermayenin oluşumunda önemli role sahiptirler. İnsan sermayesi, çalışanların eğitim, bilgi, beceri ve yeteneklerini ifade etmektedir (Görmüş, 2009). Üniversiteler, sadece ögrrencilere meslek kazandırmakla kalmamakta, aynı zamanda öğrencilerin yaşam biçimlerine de yön vermektedirler (Baskan, 2001). Toplumsal hayatta bu denli önemli rol oynayan üniversitelerinin temel performans göstergesi öğrencileri ne ölçüde memnun ettiğidir (Yüksel, Bilgen ve Kobal, 2018).

Öğrenci memnuniyeti genellikle bir öğrencinin eğitim deneyiminin değerlendirilmesinden kaynaklanan kısa vadeli bir tutum olarak kabul edilmektedir (Elliott ve Healy, 2001). Öğrenci memnuniyeti dolaylı olarak örgütsel performansı etkilemektedir. Ayrıca, memnun bir mezunun kuruma finansal olarak katkıda bulunma olasılığı daha yüksektir (Stutler ve Calvario, 1996).

Öğrencilerin geri bildirimleri, memnuniyetin düşük olduğu faktörleri iyileştirmek için kullanılabilir (Douglas, Douglas ve Barnes, 2006) ve öğrenci memnuniyetinin kurumun algılanan kalitesi ile ilişkili olduğu bulunmuştur (Athiyaman, 1997; Hanssen ve Solvoll, 2015). Üniversite ile ilgili öğrenci memnuniyeti, literatürde yıllar boyunca büyük ilgi görmüştür. Bunun temel nedenleri üç yönlüdür. Öncelikle, üniversite ile ilgili memnuniyetin kendi başına önemli bir eğitim sonucu olduğu söylenebilir. İkincisi, üniversite ile öğrenci memnuniyeti arasındaki ilişkinin karmaşık ve iki yönlü olduğu kabul edilmekle birlikte, memnuniyetin öğrenci performansı ile ilgili olduğunu gösteren kanıtlar bulunmaktadır. Memnuniyetin performans üzerinde, memnuniyetten daha yüksek bir etkiye sahip olup olmadığı hala tartışılmaktadır. Üçüncüsü, memnuniyet, üniversitede öğrencinin kalıcılığının bir göstergesi olarak kabul edilir (Lee, Jolly, Kench ve Gelonesi, 2000) 
Doğrusal, lojistik ve siralı regresyon yöntemlerinin uygulanması büyük ölçüde bağımlı değişkenlerinin ölçeğine ve model varsayımlarının geçerliliğine bağlıdır. Bağımlı değişkenler arasında kesikli ve sürekli ölçek ayrımı yapılabilmektedir. Lineer regresyon analizi, sürekli bir ölçekte ölçülen bağımlı değişkenine uygulanabilirken, lojistik regresyon analizi sadece bağımlı değişkenin ikili sonuç vermesi durumunda kullanılabilmektedir (Chen ve Hughes, 2004; Korkmaz, Güney ve Yiğiter, 2012).

Değişkenler arası ilişkileri incelemede en çok kullanılan istatistik yöntemlerinden biri regresyon analizidir. Regresyon analizlerinde genelde bağımlı değişken ölçülebilir nitelikte olmakla birlikte aynı zamanda sürekli bir değişken olabilir (Kalayc1, 2010). Ancak her zaman bağımlı değişken ölçülebilir özellikte olmayabilir. Bu tip durumlarda lojistik regresyon analizi kullanılır. Lojistik regresyon analizi, bağımlı değişkenin 0 ve 1 gibi ikili (binary) ya da ikiden çok düzey içeren kesikli değişken olması durumunda doğrusal regresyon analizine alternatif olmaktadır (Coşkun, Kartal, Coşkun ve Bircan, 2004).

Doğrusal, lojistik ve sıralı regresyon gibi regresyon yöntemleri, çok sayıda açıklayıcı değişken ile öğrenci memnuniyeti sonuçları arasındaki ilişkiyi analiz etmek için kullanılan yararlı araçlardır (Hummel ve Lichtenberg, 2001; Thomas ve Galambos, 2004).

$\mathrm{Bu}$ çalışmada öğrencilerin okudukları bölümlerinden memnun olmalarında etkili olan değişkenleri belirlemek için sıralı lojistik regresyon yöntemi kullanılmıştır.

\section{2. Üniversite Öğrencilerinin, Üniversite ve Bölümlerinden Duydukları Memnuniyetleri Üzerine Yapılmış Çalışmalar}

Öğrencilerin üniversiteden duymuş olduğu memnuniyet, çok çeşitli faktörlerden etkilenmekte, aynı zamanda birçok tutum ve davranış üzerinde de olumlu veya olumsuz olarak etki göstermektedir (Yüksel vd., 2018). Aşağıda üniversiteöğrenci etkileşiminin sonuçları üzerine yapılan çalışmalara yer verilmiştir.

Butt ve Rehman (2010) çalışmalarında, Pakistan'daki üniversite öğrencilerinin üniversitelerinden memnuniyetlerini etkileyen faktörleri incelemektedir. Araştırmacılar çalışmalarında öğretmenlerin uzmanlık, sunulan kurslar, öğrenme ortamı ve sınıf olanakları gibi faktörlere odaklanmaktadır. Araştırmanın örneklem büyüklüğünü birbirinden farklı özel ve kamu üniversitelerine ait 350 öğrenci oluşmaktadır. Regresyon analizi sonuçları, yukarıda bahsi geçen tüm faktörlerin, üniversite öğrencilerinin üniversiteden memnuniyetleri üzerinde önemli ve olumlu bir etkisi olduğunu ortaya koymaktadır. Ayrıca, öğretmenlerin uzmanlığı tüm değişkenler arasında en etkili faktördür.

O'Driscoll (2012) misafirperverlik yönetimi bölümü öğrencilerinin İrlanda'daki bir yüksek öğrenim üniversitesinde memnuniyet ve hizmet kalitesi algılarına katkıda bulunan temel faktörleri araştırmayı amaçlamaktadır. Memnuniyet değişkenleri arasındaki belirgin ilişkileri araştırmak için veri setine korelasyon analizi ve çoklu regresyon teknikleri uygulanmıştır. Analiz, öğrenci memnuniyetinin çok boyutlu bir yapısını ortaya koymaktadır. Altta yatan altı faktör, öğrenci memnuniyetini açıklamada yüksek oranda varyans oluşturmuştur. Bu altı faktör, tesisler, akademik destek, refah desteği, geribildirim, yerleşim desteği ve örgüt iletişimidir.

Erdoğan ve Bulut (2015) İktisadi ve İdari Bilimler Fakültesi İşletme bölümüne devam eden öğrencilerin memnuniyet düzeylerini etkileyen faktörleri tespit etmeyi amaçlamaktadırlar. 215 öğrenciye uygulanan anketten elde edilen verilere ilk olarak açıklayıcı faktör analizi yapmışlar, analiz sonucunda öğrencilerin memnuniyetlerini etkileyen dört faktör bulunmuştur. Bu faktörleri eğitim ve öğretim programlarının yeterliliği, destek hizmetleri, ilişkiler ve fiziksel olanaklar olarak isimlendirmişlerdir. Bu faktörlerin ve öğrencilerin demografik özelliklerinin öğrencilerin memnuniyet düzeyine etkisi sıralı regresyon analizi ile ölçülmüşlerdir. Bu analiz sonucunda sınıf düzeyi değişkeninin memnuniyet düzeyine etkisi olduğu ortaya çıkmıştır.

Osman, Saputra ve Saha (2017) hizmet kalitesi, program kalitesi ve öğrenci memnuniyeti arasındaki ilişkiyi yükseköğretim bağlamında incelemek istemişler, yapısal eşitlik modellemesini bağımsız değişkenlerin ve hipotez testlerinin etkisini analiz etmek için kullanmışlardır. Bangladeş'teki farklı özel üniversitelerde okumakta olan 331 ögrencilerden elde edilen verilerin analizi sonucunda hizmet kalitesi ve program kalitesinin, öğrenci memnuniyeti üzerinde istatistiksel olarak anlamlı bir etkiye sahip olduğu ortaya çıkarılmıştır.

Korkulu ve Albez (2018) yürüttükleri çalışmalarında, Atatürk Üniversitesi Aşkale Meslek Yüksekokulu'nda okuyan öğrencilerin okudukları bölümlerden memnuniyetleri üzerinde etkili olabilecek faktörler (demografik faktörler, okulun fiziksel yeterliliği, akademisyenler vb.) belirlenmeye çalışmışlardır. Sıralı lojistik regresyon analizi sonucunda araştırmacılar, 0,05 önem seviyesinde öğrencilerin sınıfları, başarı durumu, kaldıkları yer, bölümü araştırarak tercih edip etmeme durumu, iş olanaklarının fazla olması düşüncesi, sınıfta kendini ifade edebilmesi ve ailedeki öğrenci sayısının, bölüm memnuniyeti üzerinde etkili olduğunu tespit etmişlerdir.

\section{Metodoloji}

Araştırmanın yöntemi, çalışma evreni, veri toplama aracı, verilerin toplanması ve verilerin analizi aşağıda başlıklar halinde incelenmektedir.

\subsection{Araştırmanın Yöntemi}

Araştırma nicel bir çalışma olup, ilişkisel tarama modelinde icra edilmiştir. İlişkisel tarama modeli, iki ve daha çok sayıdaki değişken arasında birlikte değişimin varlığını veya derecesini belirlemeyi amaçlayan araştırma modelleridir (Karasar, 2016). Öğrencilerin öğrenim gördükleri alanla ilgili memnuniyetlerini inceleyen hem nicel hem de nitel yaklaşımda çalışmaların literatürde mevcut olduğu görülmektedir. Bu çalışmada bağımlı değişken memnuniyet düzeyi olup, kategorik bir yapıya sahiptir. Bağımsız değişkenler ise hem nicel hem de nitel değişken kategorisinde yer almaktadır. Bu çerçevede nicel desenin bu araştırmada tercih edilmesinin nedeni, bu konudaki verilerin desteklenmesini ya da yeni bulguların ortaya konmasını sağlamak amacıyladır. 
Bilimler Araştırmaları Etik Kurulu'ndan 14/02/2020 tarih ve 03 no.lu karar ile gerekli izin alınmıştır.

\section{2. Çalıșma Evreni}

Çalıșmanın evrenini, Aydın Adnan Menderes Üniversitesi Nazilli İIBF'nin farklı bölümlerinde okumakta olan öğrencilerin tamamı oluşturmaktadır. Bu akademik birimde öğrenim gören öğrencilerin tamamı Aralık 2019 tarihi itibariyle 6000 kişidir ve bu sayı araştırmanın ulaşılabilir evrenini temsil etmektedir. Nazilli İ̈BF'de ulaşılabilir evren içerisindeki bölümler Çalışma Ekonomisi ve Endüstri İlişkileri, İktisat, İșletme, Maliye, Siyaset Bilimi ve Kamu Yönetimi, Sosyal Hizmetler, Uluslararası İlişkiler ile Uluslararası Ticaret ve Finansmandır.

Krejcie ve Morgan'a göre (1970), evrenin 6000 kişi olması halinde örneklem büyüklüğ̈̈ 361 kişidir. Bu çalışmada, tesadüfi olarak seçilmiş 676 öğrenci ile anket yapıldığından çalışma sonuçlarının daha yüksek bir tutarlılıkla genellenebilmesi mümkün hale getirilmiştir.

\subsection{Veri Toplama Aracı}

Araştırmada veri toplama araçlarından biri olan anket tekniği kullanılmıştır. Çalışmanın amacı doğrultusunda ilk olarak öğrencilere uygulanacak olan anketin tasarlanması yoluna gidilmiş, anketin iki bölümden oluşmasına karar verilmiştir. İlk bölümde katılımcıların demografik özelliklerini belirlemeye yönelik 7 soru bulunmaktadır (cinsiyet, yaş, okuduğu bölümü kaçıncı tercihinde kazandığı, bölümü, sınıfı, öğrenim türü, barınma durumu). İkinci bölüm, öğrencilerin memnuniyetlerini ölçmeye dönük beşli Likert cevap bileşenli ("Hiç Memnun Değilim", "Az Memnunum", "Ne Az Ne Çok Memnunum", "Memnunum", "Çok Memnunum") sorudan oluşmaktadır. Çalışmanın birinci bölümündeki demografik sorular bağımsız değişkeni oluştururken, memnuniyet düzeyini ölçmeye yarayan bu soru bağımlı değişkeni oluşturmaktadır. Anket soru formu yazarlar tarafindan hazırlanmış, hazırlanma sürecinde benzer çalışmaların soru formlarından faydalanılmıştır. Bağımlı değişkenin sıralı yapıda olması nedeniyle literatürde yer alan ve sıralı lojistik regresyonun uygulandığı çalışmalara bakılmış, kullanılan anket soru formları tek tek incelenmiş ve bu çalışmada kullanılacak olan anket soru formu oluşturulmuştur. Ayrıca bağımlı değişkeni etkileyeceği düşünülen bağımsız değişkenlerin seçiminde de benzer çalışmalarda yer alan bağımsız değişkenler göz önünde bulundurularak bu çalışmaya ilave edilmiş yani diğer çalışmaların ortak bağımsız değişkenleri (istatistiki olarak anlamlı sonuç veren bağımsız değişkenler) bu çalışmanın bağımsız değişkenlerini oluşturmuştur.

\subsection{Verilerin Toplanmas}

Anket için sosyal medyaya ve Aydın Adnan Menderes Üniversitesi Nazilli İ̈BF'de yer alan duyuru panolarına anket bilgileri ve linkleri verilmiştir. Anket uygulaması 06.11.2019 ile 16.11.2019 tarihleri arasında online olarak yapılmıştır.

Uygulanan anketler için Ek - 1'de yer alan Aydın Adnan Menderes Üniversitesi Rektörlüğü Sosyal ve Beşerî

\subsection{Verilerin Analizi}

Temel istatistiksel analizler genel olarak betimsel analizler ve çıkarımsal analizler olarak iki ana başlık altında toplanmaktadır (Tüzüntürk, Taşkın ve Tuncel, 2015). Betimsel analizler verilerin tablolar, grafikler veya özet istatistikler aracilığıyla betimlenmesi ve özetlenmesi ile ilgilidir. Çıkarımsal analizler ise örneklem yardımı ile evrene ilişkin çıkarımların yapılması ile ilgilidir (Gürsakal, 2012). Çıkarımsal istatistik, örnekleme ve örnekleme dağılımı temeline dayanmaktadır (Gürsakal, 2009; Tüzüntürk vd., 2015).

$\mathrm{Bu}$ araştırmanın analizlerinde betimsel ve çıkarımsal istatistiki teknikler birlikte kullanılmıştır. Betimsel analizler için yüzde yöntemi, çıkarımsal analizler için ise sıralı lojistik regresyon yönteminden yararlanılmıştır.

\subsubsection{Stralı Lojistik Regresyon}

Regresyon yöntemleri, araştırmacıların açıklayıcı değişkenleri belirlemelerine olanak tanımaktadır. $\mathrm{Bu}$ yöntemler ayrıca araştırmacıların açıklayıcı değişkenlerin bağımlı değişken üzerindeki etkisinin büyüklüğünü tahmin etmelerine de olanak sağlamaktadır. Bu nedenle, açıklayıcı ve bağımlı değişkenler arasındaki ilişkiyi incelemede regresyon yöntemleri üstün görülmektedir (Albayrak, 2006; Chen ve Hughes, 2004).

Bağımlı değişken kategorisinin ikiden fazla olması durumunda kullanılabilecek birçok model bulunmaktadır. Bunlardan biri de multinominal lojistik regresyon modelidir. Bu model, çok kategorili ve nominal yapıdaki bağımlı değişken olasılıklarını tahmin etmede kullanılan bir yöntemdir (Field, 2005). Bazı durumlarda ise çok kategorili bağımlı değişken sıralı bir yapıda olabilir. Bağımlı değişken kategorileri aralık ölçek ile ölçülmediği ve kategoriler arasındaki uzaklıkların eşit olmadığı durumlarda bu tip veriler hem klasik regresyon ile modellenemeyecek hem de bu tip verilere multinominal lojistik regresyon analizini uygulanamayacaktır. Bahsi geçen regresyon yöntemlerinin kullanılması durumunda ise sıralı yapıdaki bağımlı değişkenin bu yapısını göz ardı edilecek ve modeller bağımlı değişkendeki tüm bilgileri kullanmakta yetersiz kalacaktır. Bu sebeplerden dolayı sıralı lojistik regresyon modelleri bu tip verilerin çözümlenmesinde geniş bir kullanım alanı bulmaktadır (Barak, Saraçbaşı, Halil ve Arıogul, 2005).

Sıralı lojistik regresyon yöntemi, bağımlı değişkeninin üç veya daha fazla kategori içerdiği ve değerlerin sıralı ölçekle elde edildiği durumlarda; bağımlı değişken ile bağımsız değişkenler arasındaki neden sonuç ilişkisini ortaya koyan bir yöntemdir (Özdamar, 1997). Orantılı odds modeli olarak da bilinen sıralı lojistik regresyon modeli, bağımlı kategorik değişkeninin ikiden fazla kategoride sıralandığ 1 genişletilmiş bir lojistik regresyon türüdür. Sıralı lojistik regresyon modeli ilk olarak Walker ve Duncan (1967) tarafından önerilmiş, Agresti (2002) tarafından kümülatif bağlantı modeli olarak benimsenmiş ve modelin ismi en son 
orantılı odds modeli şekline getirilmiştir (Nwakuya ve Mmaduka, 2019).

Siralı lojistik regresyon modeli genel olarak,

$$
\operatorname{link}\left(\gamma_{j}\right)=\tau_{j}-\sum \beta_{k}^{\prime} x_{k}
$$

şeklinde ifade edilmektedir. Ancak açıklayıcı değişkenlerin farklı değerleri (açıklayıcı değişken kategorik ise) bağımlı değişkenin farklı kategorilerinde daha yüksek oranda yer alıyorsa aşağıdaki eşitlikte gösterilen genelleştirilmiş sıralı lojistik regresyon modeli kullanılır (Ayhan, 2006; McCullagh, 1980; Norusis, 2005).

$$
\operatorname{link}\left(\gamma_{j}\right)=\frac{\tau_{j}-\left[\beta_{0}+\beta_{1} X_{1}+\beta_{2} X_{2} \ldots+\beta_{k} X_{k}\right]}{\exp \left(\theta_{0}+\theta_{1} z_{1}+\theta_{2} z_{2} \ldots \ldots \theta_{1} z_{1}+\theta_{l} z_{l}\right)}
$$

Burada, $\gamma_{j}$, j. kategori için birikimli olasılık değeri,

$\tau_{j}$, j. kategorinin eşik değeri, bilinmeyen kesme noktalar1 vektörü,

$\beta_{1} \ldots \beta_{k}$, regresyon katsayıları, yer parametreleri,

$x_{1} \ldots x_{k}$, açıklayıcı değişkenler,

$\mathrm{k}$, açıklayıcı değişken sayısı,

$\beta$ ve $\theta$, bilinmeyen yer ve ölçek parametreleri vektörü,

$z_{l}$, ölçek parametreleri için açıklayıcı değişkenlerdir (Ayhan, 2006).

\subsubsection{Sirall Lojistik Regresyon Analizinde Uygun Bağlantı Fonksiyonunu Seçme}

Siralı regresyon analizini uygularken verilecek önemli kararlardan biri, bağımsız değişkenlerin hangisinin bağımlı değişken üzerinde en fazla etkisi olduğunu belirlemek ve uygun bağlantı fonksiyonunu seçmektir (Elamir ve Sadeq, 2010; Erdoğan ve Bulut, 2015).

Sıralı lojistik regresyonda kullanılan bağlantı fonksiyonları aşağıdaki gibidir (Sümbüloğlu ve Akdağ, 2009):

1.Logit: Bağımlı değişkenin her bir kategorisindeki denek sayısı dağılımı benzerse kullanılır.

2.Complementary log-log: Bağımlı değişkende yüksek kategorili ile temsil edilen kategorilerde denek sayısı daha fazla ise kullanılır.

3.Negative log-log: Bağımlı değişkende düşük kategorili ile temsil edilen kategorilerde denek sayısı daha fazla ise kullanılır.

4.Probit: Gizli (latent) değişkenin dağılımı yaklaşık olarak normal dağılıyor ise kullanılır.

5.Cauchit: Gizli (latent) değişken birçok aşırı değere sahipse kullanılır.

$\mathrm{Bu}$ çalışmada bağımlı değişkende yükssek kategorili ile temsil edilen kategorilerde denek sayısı daha fazla olması nedeniyle kullanılacak olan uygun bağlantı fonksiyonu Complementary log-log'dur.

\subsubsection{Siralı Lojistik Regresyon Modelinin Paralel Ĕgriler Varsayımı}

Siralı lojistik regresyon modellerinde siralı oranlara ait önemli bir varsayım vardır. $\mathrm{Bu}$ varsayımlara göre parametreler farklı kategoriler için değişmemelidir. Başka bir deyişle, bağımsız değişken ve bağımlı değişken arasındaki korelasyon bağımlı değişkenin kategorileri için değişmez, aynı zamanda kesme noktaları için parametre tahminleri değişmez (Arı ve Yıldız, 2014; Kleinbaum ve Klein, 2010).

Paralel eğriler varsayımı olarak isimlendirilen bu varsayım reddedilirse, her kategori için ayrı katsayıları tahmin eden multinomial regresyon kullanmak gerekecektir. Eğer $\mathrm{H}_{0}$ hipotezi, belirli bir önem seviyesinde reddedilirse, seçilen link fonksiyonunun veriler için yanlış olduğu veya bağımsız değişkenler ve logitler arasındaki ilişkilerin tüm logitlerde aynı olmadığ 1 anlamına gelecektir (Adejumo ve Adetunji, 2013).

Siralı lojistik regresyon modelinden elde edilen bilginin doğru ve güvenilir olması için paralel eğriler varsayımının sağlanması gerekmektedir. Eğer bu varsayım sağlanmazsa elde edilen tüm sonuçlar hem anlamsız hem de yanlış olacaktır (Özdinç, 1999; Şerbetçi ve Özçomak, 2013).

\subsubsection{Modelin Uygunluğunun Test Edilmesi ve Modelin Performansının Değerlendirilmesi}

Siralı lojistik regresyonda uyum iyiliği, Pearson ki-kare ve sapma testleri kullanılarak değerlendirilmektedir ( $\mathrm{Bu}$ tür çalışmalarda kullanılmak için (Lipsitz vd., 1996) tarafından Pearson ki-kare ve sapma istatistiklerine alternatif bir uyum iyiliği istatistiği de önerilmektedir). Bu testler, satırları model ortak değişkenlerinin tüm olası çapraz sınıflandırmalarından ve sütunları sıra yanıt seviyelerinden oluşan bir olasılık tablosu oluşturmaya yol açmaktadır (Pulkstenis ve Robinson, 2004).

Siralı lojistik regresyon modelinin uyumu, bağımsız değişkenlerin sayısına ve model oluşturma aşamasında karar verilerek seçilen bağlantı fonksiyonuna bağlıdır. Araştırmacılar model uyumu istatistiklerine ve öngörülen sınıflandırmanın doğruluğuna dayanarak sıralı bir lojistik modelin performansını değerlendirebilir. Pearson ki-kare ve sapma uyum iyiliği istatistikleri gibi model uyumu istatistikleri, her oluşum için beklenen ve gözlenen sıklığa bağlı olarak model uyumunu ölçmektedir. Ek olarak, bağımsız ve bağımlı değişkenler arasındaki kuvvet ilişkisini ölçmek için, sözde $\mathrm{R}^{2}$ gibi olasılık oranına bağlı olan model istatistikleri de kullanılabilir. Sıralı bir regresyon modelinde sahte $\mathrm{R}^{2}$ 'sini yorumlamanın yolu, doğrusal regresyon modellerinde $\mathrm{R}^{2}$ 'ninkine benzer (Larasati, DeYong ve Slevitch, 2011).

\subsubsection{Model Parametrelerin Yorumlanması}

Siralı lojistik regresyon modelindeki model parametreleri kolayca yorumlanabilmektedir. Model sadece ana etkiyi içeriyorsa, her parametre, her bir tahmin değişkeninin ağırlığını belirtir. Ayrıca, bu parametre, her parametrenin modele olan önemini incelemek için istatistiksel olarak test edilebilir. $\mathrm{Bu}$ nedenle, sıralı lojistik regresyonun çok kullanılan bir istatistiksel araç olmasının nedeni, model parametresinin yorumlanabilirliğine ve kullanım kolaylığına bağlanabilir (Larasati vd., 2011).

Parametrelerin yorumlanmasında genellikle odds oranı (odds ratio) kullanılmaktadır (Üçdoğruk vd., 2001; Yakut vd., 2015). Eğer odds oranı 1'den büyükse, bağımlı değişkendeki artışla birlikte, olayın olma ya da görülme olasılığına ilişkin odds oranı yükselir. Eğer değer 1'den 
küçükse, bağımlı değişkendeki artışa karşılık olayın olma ya da görülme olasılığı düşer (Çokluk, 2010; Field, 2005).

\section{Bulgular}

Çalışmanın bu bölümünde demografik özelliklerin sunulması amacıyla betimsel ve çıkarımsal bulgulara yer verilmektedir.

\subsection{Demografik Bulgular}

Tablo 1'de 676 öğrencinden elde edilen verilere ilişkin bazı özellikler verilmektedir.

Tablo 1. Çalışma Kapsamındaki Öğrencileri Verilerine İlişkin Özellikler

\begin{tabular}{|c|c|c|c|}
\hline Değişken & Kategori & $\mathbf{N}$ & $\%$ \\
\hline \multirow{2}{*}{ Cinsiyet } & Erkek & 302 & 44,7 \\
\hline & $\overline{\mathrm{K}} \mathrm{zz}$ & 374 & 55,3 \\
\hline \multirow{2}{*}{ Yaş } & $18-21$ & 400 & 59,2 \\
\hline & $22+$ & 276 & 40,8 \\
\hline \multirow{2}{*}{ Öğrenim Türü } & Normal Öğretim & 375 & 55,5 \\
\hline & İkinci Öğretim & 301 & 44,5 \\
\hline \multirow{5}{*}{ Sinif } & 1 & 65 & 9,6 \\
\hline & 2 & 129 & 19,1 \\
\hline & 3 & 191 & 28,3 \\
\hline & 4 & 237 & 35,1 \\
\hline & $4+$ & 54 & 8 \\
\hline \multirow{8}{*}{ Bölüm } & Çalışma Ekonomisi ve Endüstri İlişkileri & 69 & 10,2 \\
\hline & İktisat & 123 & 18,2 \\
\hline & İşletme & 144 & 21,3 \\
\hline & Maliye & 115 & 17 \\
\hline & Siyaset Bilimi ve Kamu Yönetimi & 69 & 10,2 \\
\hline & Sosyal Hizmetler & 23 & 3,4 \\
\hline & Uluslararası İlişkiler & 84 & 12,4 \\
\hline & Uluslararası Ticaret ve Finansman & 50 & 7,4 \\
\hline \multirow{3}{*}{$\begin{array}{l}\text { Barınma } \\
\text { Durumu }\end{array}$} & Ailemin Yanımda-Evde Tek Başıma & 116 & 17,2 \\
\hline & Apart & 366 & 54,1 \\
\hline & Devlet Yurdu & 194 & 28,7 \\
\hline \multirow{4}{*}{ Memnuniyet } & Memnun Değilim & 51 & 7,5 \\
\hline & Ne Memnunum Ne Değilim & 99 & 14,7 \\
\hline & Memnunum & 526 & 77,8 \\
\hline & Toplam & 676 & 100 \\
\hline
\end{tabular}

Tablo 1'de yer alan frekans değerleri incelendiğinde ankete katılan öğrencilerin \%55,3'ünün k1z öğrencilerden oluştuğu, \%59,2'sinin 18-21 yaş aralığında olduğu, $\% 55,5$ 'inin normal öğretimde, \%35,1'inin 4. sinıfta, \%21,3'ünün işletme bölümünde okuduğu, yarıdan fazlasının kiralık apartlarda kaldığı anlaşılmaktadır. Aynı tablodan, okuduğunuz bölümden memnun musunuz sorusuna 51 öğrencinin $(\% 7,5)$ memnun değilim, 99 öğrencinin $(\% 14,7)$ ne memnunum ne de memnun değilim, 526 öğrencinin ise $(\% 77,8)$ okuduğum bölümden memnunum cevabını verdiği görülmektedir.

\section{2. İstatistiki Bulgular}

\subsubsection{Paralel Ĕ̈riler Varsayımı}

Bir önceki bölümde de bahsedildiği gibi, sıralı lojistik regresyon modelinin uygulanabilmesi için birtakım varsayımların sağlanması gerekmektedir. $\mathrm{Bu}$ varsayımlardan en önemlisi paralellik varsayımıdır.

Paralel eğriler varsayımının test edilmesinde $\mathrm{H}_{0}$ ve $\mathrm{H}_{1}$ hipotezi aşağıdaki şekilde kurulur (Şerbetçi ve Özçomak, 2013):
$\mathrm{H}_{0}$ : İlişkili regresyon katsayıları, bağımlı değişkenin tüm kategorilerinde aynıdır.

$\mathrm{H}_{1}$ : İlişkili regresyon katsayıları, bağımlı değişkenin tüm düzeylerinde farklıdır.

Çalışmada bağımlı değişken olan memnuniyet düzeyi 5'li likert cevap bileşeni ile ifade edilmeye çalışılmış, paralellik varsayımının sağlanamaması nedeniyle 3'lü likert cevap bileşenine indirgenmiştir.

Tablo 2. Paralel Eğriler Varsayımı Testi

\begin{tabular}{ccccc}
\hline & -2 Log Likelihood & Ki-Kare & s.d. & P \\
\hline Yokluk Hipotezi & 766,031 & & & \\
\hline Genel & 752,519 & 13,512 & 10 & 0,196 \\
\hline
\end{tabular}

Tablo 2'nin son sütununa bakıldığında $\mathrm{p}$ değerinin anlamlılık düzeyi olan 0,05 'ten büyük olduğu görülmektedir $(p=0,196>0,05)$. Aynı zamanda Ki-kare tablosuna bakıldığında tablo değerinin $\left(\chi_{(0,05 ; 10)}^{2}=18,307\right)$, hesap değerinden $(13,512)$ büyük olduğu sonucuna ulaşılmaktadır. Her iki sonuç bize $\mathrm{H}_{0}$ hipotezinin kabul edilmesi gerektiğini açıklamaktadır. Bir başka ifade ile "İlişkili regresyon katsayıları, bağımlı değişkenin tüm kategorilerinde aynıdır" hipotezi kabul edilmiş, varsayım sağlanmıştır.

\subsubsection{Modelin Uyum İyiliğinin Test Edilmesi}

Verilerin modele uyup uymadığı, aşağıdaki hipotezlerin test edilmesi ile karar verilmektedir (Akın ve Şentürk, 2012).

$\mathrm{H}_{0}$ : Model, verileri itibariyle uygundur.

$\mathrm{H}_{1}$ : Model, verileri itibariyle uygun değildir.

Tablo 3'te uyum iyiliği test istatistiklerine yer verilmektedir.

Tablo 3. Uyum İyiliği Testi

\begin{tabular}{|c|c|c|c|}
\hline & Ki-Kare & s.d. & $\mathrm{P}$ \\
\hline Pearson & 903,818 & 922 & 0,659 \\
\hline Sapma & 676,636 & 922 & 1,000 \\
\hline \multicolumn{4}{|c|}{ Pseudo $\mathrm{R}^{2} \overline{\text { Değerleri }}$} \\
\hline Cox and Snell: 0,032 & Nagelkerke: 0,043 & & \\
\hline
\end{tabular}

Modelin uyum iyiliği, Sapma ve Ki-kare değerlerine bakılarak belirlenmektedir. Test istatistiklerine ait olasıllk değerlerine bakıldığında her iki olasılık değerinin 0,05 'ten büyük olduğu görülmektedir. Bu sonuçlara göre $\mathrm{H}_{0}$ hipotezi kabul edilir. $\mathrm{Bu}$ sonuçlara göre modelin verilerle uyum içerisinde olduğunu, modelin uyum iyiliğinin sağlandığ görülmektedir.

Tablo 4. Model Uygunluk Bilgileri

\begin{tabular}{ccccc}
\hline Model & -2 Log Likelihood & Ki-Kare & s.d. & P \\
\hline Sadece Kesişim & 787,967 & & & \\
\hline Final & 766,031 & 21,937 & 10 & 0,015 \\
\hline
\end{tabular}

Ki-kare test istatistik değerinin yer aldığ 1 Tablo 4'e göre Kikare test değeri anlamlıdır $(\mathrm{p}<0.05)$. Bir başka ifade ile, son modelin, sadece kesişim temelli modele göre anlamlı bir gelişme sağladığı söylenebilir (Erdoğan ve Bulut, 2015).

\subsubsection{Parametrelerin Yorumlanmast}

İlgilendiğimiz sıralı lojistik regresyon modelinde bir bağımlı değişken ve yedi bağımsız değişken bulunmaktadır. 
Bağımsız değiş̧kenler, öğrencilerin Aydın Adnan Menderes Üniversitesi Nazilli İ̈BF'nin ilgili bölümlerini kaçıncı tercihlerinde kazandıkları, cinsiyetleri, yaşları, anketin uygulandığı anda kaçıncı sınıfta oldukları, öğrenim durumları ve barınma durumlarıdır. Tablo 5 'te $\beta$ katsayıları, katsayıların standart hataları, Wald değerleri, odds oranları $\left(e^{\beta}\right)$ (tabloda yalnızca 0,05 anlamlılık düzeyinde anlamlı olan değişkenlerin odds oranlarına yer verilmektedir) ve olasılık değerleri (p) bulunmaktadır.

Tablo 5. Memnuniyeti Etkileyen Bağımsız Değişkenlere Ait İstatistikler

\begin{tabular}{|c|c|c|c|c|c|c|}
\hline & & $\beta$ & $\begin{array}{c}\text { Standart } \\
\text { Hata }\end{array}$ & Wald & $e^{\beta}$ & $\mathrm{p}$ \\
\hline \multirow{2}{*}{$\begin{array}{l}\text { Eşik } \\
\text { Değerler }\end{array}$} & Memnuniyet=1 & $-2,231$ &, 347 & 41,280 & &, 000 \\
\hline & Memnuniyet=2 & $-1,055$ & ,329 & 10,303 & & 001 \\
\hline \multirow{15}{*}{$\begin{array}{c}\text { Bağımsız } \\
\text { Değişkenler }\end{array}$} & Tercih Sirası &,- 007 & ,013 & ,244 & & ,621 \\
\hline & Cinsiyet $=1$ &,- 406 &, 168 & 5,814 & 0,666 &, 016 \\
\hline & Cinsiyet $=2$ & $0^{\mathrm{a}}$ & . & . & &. \\
\hline & Yaş=1 &,- 187 & 208 & ,802 & & ,371 \\
\hline & Yaş $=2$ & $0^{\mathrm{a}}$ &. &. & & . \\
\hline & Sinıf $=1$ & ,979 & ,437 & 5,013 & 2,662 &, 025 \\
\hline & Sinıf $=2$ & ,986 & ,375 & 6,905 & 2,680 & ,009 \\
\hline & Sinıf $=3$ & 820 & ,328 & 6,254 & 2,270 & 012 \\
\hline & Sinif $=4$ & ,286 & 279 & 1,057 & 1,331 & ,304 \\
\hline & Sinif $=4+$ & $0^{\mathrm{a}}$ &. & . & & . \\
\hline & Öğrenim=1 &, 112 & , 166 & ,461 & & ,497 \\
\hline & Öğrenim $=2$ & $0^{\mathrm{a}}$ &. &. & & . \\
\hline & Barınma $=1$ &,- 177 & 254 & ,489 & & ,484 \\
\hline & Barınma=2 &, 128 & 211 & ,367 & &, 545 \\
\hline & Barınma $=3$ & $0^{\mathrm{a}}$ & 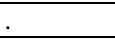 &. & & \\
\hline
\end{tabular}

Yukarıda verilen tablo incelendiğinde değişkenlerin referans kategorilerinin son kategoriler olduğu görülmektedir. Bu nedenle sonuçlara ilişkin yorumlar da her değişkene ait referans kategorileri baz alınarak yapılacaktır. Yorumlar bu referans kategoriler üzerinden ve odds oranına $\left(e^{\beta}\right)$ göre yorumlanacaktır.

Odds oranı bir olayın meydana gelme olasıllı̆ının meydana gelmeme olasılığına oranlanmasıyla bulunmaktadır. Ayrıca odds oranı, Bağımlı değişkeninin bağımsız değişkeninin etkisiyle kaç kat daha fazla ya da yüzde kaç fazla oranda gözlenme olasilığına sahip olduğunu belirtir (Özdamar, 1999).

Cinsiyet değiş̧kenine ait $\mathrm{p}$ değerinin 0,05 'ten küçük olması nedeniyle cinsiyet değişkeni ile memnuniyet değişkeni arasındaki ilişki istatistiksel olarak anlamlıdır $(\mathrm{p}=0,016<0,05)$. Cinsiyet değişkeni için odds oranı 0,666 olarak bulunmuştur. Cinsiyet değişkeninin $\beta$ katsayısının negatif olmasından dolayı Odds oranı 1'den küçük değer almakta ve bu değişken için yorum yaparken azdır ifadesini kullanmak gerekmekte iken, fazladır ifadesinin kullanılabilmesi için 1 'in odds oranına bölünmesi gerekmektedir. Cinsiyet değişkeninde kadın, referans kategorisi olarak ele alınmıştır. Analiz sonuçlarına göre erkek öğrencilerin okudukları bölümlerinden memnun olma olasılı̆̆ı, kız öğrencilerin okudukları bölümden memnun olma olasılığından 0,666 kat daha fazladır. Başka bir ifade ile, kız öğrenciler okudukları bölümlerinden, erkek öğrencilere göre 1,50 kat daha fazla memnundur.

Sınıf değişkeninde referans kategori, lisans öğrenimini 4 yılda tamamlayamayan öğrencilerdir. 1. sinıfta okuyan öğrencilerin bölümlerinden memnun olma olasilıkları okulunu dört yılda tamamlayamayan öğrencilerin bölümlerinden memnun olma olasilığından 2,662 kat, 2 . sinıfta okuyan öğrencilerin bölümlerinden memnun olma olasılıkları okulunu dört yılda tamamlayamayan öğrencilerin bölümlerinden memnun olma olasıllğından 2,680 kat, 3. sinıfta okuyan öğrencilerin bölümlerinden memnun olma olasılıkları ise okulunu dört yılda tamamlayamayan öğrencilerin bölümlerinden memnun olma olasılığından 2,270 kat fazladır. Bulunan sonuçlar istatistiksel olarak anlamlıdır $\quad(p=0,025<0,05$; $\mathrm{p}=0,009<0,05 ; \quad \mathrm{p}=0,012<0,05) . \quad 4 . \quad$ sinifta okuyan öğrencilerin bölümlerinden memnun olma olasılıkları okulunu dört yılda tamamlayamayan öğrencilerin bölümlerinden memnun olma olasıllğından 1,331 kat fazladır. Bulunan sonuç istatistiksel olarak anlamlı değildir.

Sınıf değişkeninin her bir düzeydeki $\beta$ katsayılarının sınıf arttıkça azaldığı görülmektedir. Aynı zamanda yukarıda da ifade edildiği gibi odds oranlarının 1'den büyük olduğu sonucuyla karşı karşıya kalınmaktadır. Bu durum, sınıf ilerledikçe öğrencilerin okudukları bölümlerinden memnuniyetlerinde azalma olduğu sonucuna ulaşmamızı sağlamaktadır.

Memnuniyet düzeyini etkileyeceği düşünülen ve çalışmada yer verilen diğer değişkenlerin (tercih sırası, yaş, öğrenim türü ve barınma durumu değişkenlerinin) memnuniyet değiş̧eni üzerinde istatistiksel olarak anlamlı bir etkisi bulunmamaktadır.

\section{Sonuç, Tartışma ve Öneriler}

Üniversitede okuyan öğrencilerin hem üniversiteye hem de bölümlerine duydukları memnuniyeti etkileyen faktörlerin belirlenmesi ve üniversitelere kayıt yaptıracak farklı özelliklere sahip öğrencilerin gelecekteki başarı durumlarının tahmin edilmesi tüm alanlarda çalışan araştırmacıların ilgisini çeken bir konu olmuştur. $\mathrm{Bu}$ konuyla ilgili yapılan çalışmalara bakıldığında analiz aşamasında birbirinden farklı istatistiksel yöntemlerin kullanıldığı da görülmektedir.

$\mathrm{Bu}$ çalışmada öğrencilerin bölümlerinden memnun olupolmamalarında etkisi bulunan faktörler, sıralı lojistik regresyon analiziyle belirlenmeye çalışılmıştır. Çalışmada ilk olarak üniversitelerin bulundukları bölgeye katkıları üzerine yapılan araştırmalardan bahsedilmiş, araştırmalar sonucunda öğrencilerin, üniversitelerin verdikleri eğitimden memnun olmaları durumunda bu tür katkıların gerçekleşebileceği sonucuna varılmıştır. Yine bu çalışmada konuyla ilgili yapılmış diğer çalışmalara da yer verilmiş, öğrencilerin okudukları üniversitelerden duydukları memnuniyetleri etkileyen etmenlerin birbirinden farklı olduğu görülmüştür.

Umbach ve Porter (2002) 1300 mezundan elde edilen anket verilerini analiz ederek, akademik bölümlerin öğrenci memnuniyeti ve gelişimi üzerindeki etkisini incelemişlerdir. Çalışmada öğrenci memnuniyetini etkileyen birçok faktör bulunmuştur. Bunlardan ikisi farklı bölümlerde/fakültelerde öğrenim görme ve cinsiyettir. Tessema, Ready ve Malone (2012) çalışmalarında cinsiyetin, öğrenci memnuniyeti üzerinde anlamlı bir etkiye sahip olduğu, kız öğrencilerin erkek öğrencilere oranla üniversite ve bölümlerinden daha fazla memnun oldukları sonucuna ulaşmışlardır. Erdoğan ve Bulut (2015) çalışmalarında Ondokuz Mayıs Üniversitesi İktisadi ve İdari Bilimler Fakültesi İşletme bölümüne devam eden 
öğrencilerin memnuniyet düzeylerini etkileyen faktörleri tespit etmek ve bu faktörlerin memnuniyet düzeyleri üzerine etkisini belirlemeyi amaçlamışlardır. Çalışmadan, sınıf değişkeninin memnuniyet düzeyini etkilediği, son sınıf öğrencilerine göre diğer sinıflarda okuyan öğrencilerin okuduğu eğitim programından daha memnun olduğu sonucu çıkarılmıştır. Bu çalışmadan elde edilen sonuçlar, Umbach ve Porter (2002), Tessema vd. (2012) ile Erdoğan ve Bulut'un (2015) çalışmalarından elde edilen sonuçlarla benzerlik göstermektedir.

$\mathrm{Bu}$ çalışmada sıralı lojistik regresyon kavramından bahsedilmiş, bu analizin hangi varsayımları karşılaması durumunda uygulanabileceğine, regresyon modelinin hangi durumlarda iyi sonuçlar verebileceğine değinilmiştir. Yapilan analizler sonucunda, cinsiyet ve sinif değişkenlerinin memnuniyet düzeyi üzerinde istatistiksel olarak anlamlı bir etkiye sahip olduğu, kadın öğrencilerin erkek öğrencilere kıyasla bölümlerinden daha fazla memnun oldukları, öğrencilerin sınıf ilerledikçe memnuniyetlerinde bir azalma olduğu gerçeği ile karş1 karşıya kalınmıştır. Erdoğan ve Bulut (2015), öğrencilerin sınıf ilerledikçe memnuniyet düzeylerinde bir azalma olmasının temel sebebini, öğrencilerin son sınıfa geldiklerinde, üniversite sonrası oluşacak yaşam kaygılarının artması ve bölümleriyle ilgili beklentilerinin maksimum seviyeye ulaşması olarak görmektedirler.

$\mathrm{Bu}$ çalıșmada öğrenim durumu ve barınma durumu değişkenlerinin memnuniyet düzeyi üzerinde anlamlı bir etki oluşturmadığı görülmektedir. Buna karşın her iki değişkenin, öğrencilerin başarı durumları üzerinde etkisinin olduğu çalışmalar da bulunmaktadır (Kalfa ve Karagül, 2014). Buradan şu sonucu çıkarmak mümkündür: Başarıyı veya not ortalamasını doğrudan etkileyen değişkenler, öğrencilerin bölümlerinden memnun olmalarını etkilememektedir.

Çalışmada öğrencilerin okudukları bölümü tercih etme sırasının, memnuniyet üzerinde istatistiksel olarak anlamlı bir etki oluşturmadığı görülmüştür. Bulunan bu sonuç her iki türlü de değerlendirilebilir. İlki, okudukları bölümü ilk sıralarda tercih eden ögrencilerin istedikleri memnuniyeti elde edememeleri, ikincisi ise okudukları bölümü orta veya son sıralarda tercih eden öğrencilerin okudukları bölümü istemeyerek tercih etmelerine rağmen beklenenden daha fazla memnuniyet düzeyine ulaşmalarıdır.

$\mathrm{Bu}$ çalışmada üniversite öğrencilerinin bölümlerinden duydukları memnuniyeti etkileyen faktörler sıralı lojistik regresyon yöntemi ile belirlenmeye çalışılmıştır. Bundan sonraki çalışmalarda fakültelere veya üniversitelere duyulan memnuniyeti etkileyen faktörler incelenebilir ve farklı istatistiksel yöntemler vasıtası ile elde edilen sonuçlar, bu çalışmadan elde edilen sonuçlar ile karşılaştırılabilir. Yapılacak araştırmalarda aynı ya da benzer analiz yöntemleri kullanılabileceği gibi farklı desenler de kullanılarak memnuniyeti etkileyen faktörler incelenebilir (yapay sinir ağları, bulanık mantık gibi yöntemler kullanılabilir).

$\mathrm{Bu}$ çalışmadan sonraki çalışmalarda kullanılacak olan bağımsız değişkenlerin sayısı ve çeşitliliği artırılabilir (bölümlerde bulunan dersleri sayısı, derslerin yabancı dilde anlatılıp-anlatılmaması, öğretim üyelerinin ders anlatma tekniği gibi). Bilindiği gibi bağımlı değişkendeki değişimin ne kadarının bağımsız değişkenler tarafından açıklandığını gösteren $\mathrm{R}^{2}$, bağımsız değişken arttıkça artmaktadır.

Öğrencilerin akademik başarılarında, okudukları bölümlerinin etkisinin olduğuna yönelik çalışmalar da bulunmaktadır. Özer ve Sarı (2009) çalışmalarında üniversite öğrencilerinin başarılarını etkileyen faktörleri tespit etmeyi amaçlamışlardır. Araştırmacıların elde ettikleri bulgulara göre; öğrencilerin öğrenim gördükleri bölümleri, akademik başarılarında istatistiksel olarak etkilidir. Yapılacak olan diğer çalışmalarda öğrenim görülen bölüm ile başarı durumu arasındaki ilişki de kapsama alınmalıdır.

Kurt ve Erdem (2012) yaptıkları çalışmalarında öğrencilerin başarılarını etkileyen faktörleri veri madenciliği yöntemi ile incelenmişlerdir. Araştırmacılar başarısızlığa etki eden faktörlerin başında istemediği bölümde okumanın geldiğini tespit etmişler, başarısız öğrencilerin çoğunun istemediği bölümde okuduğunu saptamışlardır. Ayrıca, mezuniyet sonrası bölümle ilgili bir işte çalışıp çalışmama ihtimalinin başarıyı ciddi şekilde etkilediği belirlenmiş, cinsiyetin başarıda etkin olarak belirleyici bir etkisi bulunamamıştır.

Öğrencilerin bölümlerinden memnun olmaları, okudukları üniversiteden memnun olmalarını da etkilemektedir. Khan ve Almas (2013) sıralı lojistik regresyon yöntemini kullanarak yaptıkları çalışmada, bölümlerin öğrencilerin beklentilerini karşılamasının ve öğrencilerin fakülte dekanına erişilebilmesinin, okudukları üniversitelerinden memnun olmalarında önemli bir faktör olduğunu ortaya çıkarmışlardır.

Öğrencilerin öğrenim gördükleri bölümlerinden, fakültelerinden, üniversitelerinden memnuniyet durumlarını etkileyebilecek faktörlerin belirlenmesi amacıyla, keşfedici özellikte ve karma yaklaşımda araştırmaların yürütülmesi, konuya farklı bakış açılarıyla yeni perspektifler kazandıracağı öngörülmektedir. Bu amacı gerçekleştirebilmek için çoklu veriler toplanmalı, nicel ve nitel yaklaşımlar birlikte kullanılmalıdır. Karma yaklaşımın temel dayanağı, nicel ve nitel yaklaşımların birlikte kullanılmasının, araştırma problemlerinin tek başına yaklaşımlardan daha iyi anlaşılmasını sağlamasıdır (Creswell, 2006).

Şeker, Çınar ve Özkaya (2004), çalışmalarında üniversite öğrencilerinin başarılarında, çevresel faktörlerin etkilerini belirlemeyi amaçlamışlardır. Çalışmadan elde edilen bulgulara bakıldığında, öğrencilerin lise bitirme derecelerinin lisans başarıları üzerinde etkili olduğu anlaşılmaktadır. Çalışmada liseyi pekiyi derece ile bitiren öğrencilerin not ortalamaları, birbirine benzer ortalamaya sahip iyi ve orta derece ile mezun olanlardan daha yüksek bulunmuştur. Buna göre; üniversitedeki eğitim veriminin artırılabilmesi için lisedeki verimin de artırılması gerekir. Burada lise okul müdürlerine ve öğretmenlerine çok iş düşmektedir. Öğretmenler, öğrencilerin başarılarını artırabilmek için öğrencilerin istek ve ihtiyaçlarını karşılayabilecek donanımda, öğrenci ile iletişim halinde ve öğrencilerin karşılaştıkları sorunlara kalıcı çözümler üretebilir olmalıdır. Okul yöneticileri ise öğrencilerin rahatça çalışabilecekleri fiziksel imkanları sağlamalı ve başarılı öğrencileri ödüllendirmelidir. 
Lojistik regresyon (dolayısıyla sıralı lojistik regresyon) parametrik olmayan (nonparametrik) bir istatistiksel yöntemdir. Bu yöntem ile parametrik yöntemler (ayırma analizi) aynı çalışmada kullanılabilir ve her iki yöntemle bulunan sonuçlar karşılaştırılabilir.

$\mathrm{Bu}$ çalışmada paralel eğriler varsayımının geçerliliğinin test edilmesinde ki-kare test istatistiğinden yararlanılmıştır. Paralel eğriler varsayımının sınanmasında başka test istatistikleri de bulunmaktadır (olabilirlik oran testi, wald testi). Kullanıcilara bu test istatistiklerinden yararlanmaları ve sonuçları karşılaştırılmaları tavsiye edilmektedir.

Sıralı lojistik regresyonda bağımlı değişkenin sıralı olduğu ve kategoriler arasında paralellik varsayımı sağlandığı durumda kümülatif olasılıkların tahmini temeline dayanan ve çalışmalarda yaygın olarak kullanılan sıralı lojistik regresyon modeli orantısal oran modelidir (Ar1 ve Y1ldiz, 2016). Bağımlı değişkenin sıralı yapıda olması ve paralellik varsayımını sağlaması nedeniyle bu çalışmada kullanılan siralı lojistik regresyon modeli, orantısal oran modelidir.

Oransal oran modelindeki bağımsız değişkenlerin paralel doğrular varsayımını kesinlikle sağlaması gerekmektedir. Paralel doğrular varsayımının bazı değişkenler için sağlanıp bazı değişkenler için sağlanmadığı durumlarda kısıtlandırılmamış kısmi oransal oran modeli kullanılmaktadır (Dağlıŏlu ve Erbaş, 2017; McCullagh ve Nelder, 1989). Uygulayıcılara, çalışmalarında kısıtlandırılmamış kısmi oransal oran modeli kullanmaları ve buldukları sonuçları, oransal oran modelindeki sonuçlarla karşılaştırmaları önerilmektedir.

\section{Kaynakça}

Adejumo, A. O. ve Adetunji, A. A. (2013). Application of ordinal logistic regression in the study of students' performance. Mathematical Theory and Modeling, 3(11), 10-19.

Agresti, A. (2002). Categorical data analysis. New York: John Wiley ve Sons, Inc.

Akın, H. B. ve Şentürk, E. (2012). Bireylerin mutluluk düzeylerinin ordinal lojistik regresyon analizi ile incelenmesi. Öneri, 10(37), 183-193.

Albayrak, A. S. (2006). Uygulamalı Çok değişkenli istatistik teknikleri. Ankara: Asil Yayın Dağıtım.

Arı, E. ve Y1ld1z, Z. (2014). Parallel lines assumption in ordinal logistic regression and analysis approaches. International Interdisciplinary Journal of Scientific Research, 1(3), 8-23.

Arı, E. ve Yıldız, Z. (2016). Bireylerin yaşam memnuniyetini etkileyen faktörlerin sıralı lojistik regresyon analizi ile incelenmesi. Uluslararası Sosyal Araştırmalar Dergisi, 9(42), 1362-1374.

Athiyaman, A. (1997). Linking student satisfaction and service quality perceptions: The case of university education. European Journal of Marketing, 31(7), 528-540.

Ayhan, S. (2006). Strall lojistik regresyon analiziyle Türkiye'deki hemşirelerin iş bırakma niyetini etkileyen faktörlerin belirlenmesi (Yüksek Lisans Tezi). Yükseköğretim Kurulu Ulusal Tez Merkezi'nden edinilmiştir. (Tez No. 184033).

Barak, N. A., Saraçbaşı, O., Halil, M. ve Arığul, S. (2005). Genelleştirilmiş sıralı lojistik regresyon modeli. VIII. Ulusal Biyoistatistik Kongresi, (s. 171-180). Bursa.

Baskan, G. A. (2001). Öğretmenlik mesleği ve öğretmen yetiştirmede yeniden yapılanma. Hacettepe Üniversitesi Ĕgitim Fakültesi Dergisi, 20, 16-25.

Butt, B. Z. ve Rehman, K. (2010). A study examining the students satisfaction in higher education. Procedia Social and Behavioral Sciences, 2, 5446-5450.

Chen, C. ve Hughes, J. (2004). Using ordinal regression model to analyze student satisfaction questionnaires. Association for Institutional Research, 1, 1-13.

Çokluk, Ö. (2010). Lojistik regresyon analizi: Kavram ve uygulama. Kuram ve Uygulamada Eğitim Bilimleri, 10(3), 1357-1407.

Coşkun, S., Kartal, M., Coşkun, A. ve Bircan, H. (2004). Lojistik regresyon analizinin incelenmesi ve dişhekimliğinde bir uygulaması. Cumhuriyet Üniversitesi Diş Hekimliği Fakültesi Dergisi, 7(1), 4150.

Creswell, J. W. (2006). Understanding mixed methods Research, (Chapter 1). http://www.sagepub.com /upm-data/10981_Chapter_1.pdf adresinden alındı (Erişim tarihi: 16.02.2020).

Dağlıŏlu, H. ve Erbaş S. O. (2017). Kısıtlandırılmamış kısmi oransal odds modelinin doğru sınıflandırma performansı üzerine bir çalışma. Gazi Mühendislik Bilimleri Dergisi, 3(3), 14-26.

Dougles, J., Douglas, A. ve Barnes, B. (2006). Measuring student satisfaction at a UK university. Quality Assurance in Education, 14(3), 251-267.

Elamir, E. ve Sadeq, H. (2010). Ordinal regression to analyze employees' attitudes towards the application of total quality management. Journal of Applied Quantitative Methods, 5(4), 647-658.

Elliot, K. M. ve Shin, D. (2002). Student satisfaction: An alternative approach to assessing this important concept. Journal of Higher Education Policy and Management, 24(2), 197-209.

Elliott, K. M. ve Healy, M. A. (2001). Key factors influencing student satisfaction related to recruitment and retention. Journal of Marketing for Higher Education, 10(4), 1-11.

Erdoğan, E. ve Bulut, E. (2015). İşletme bölümü öğrencilerinin memnuniyet düzeylerini etkileyen faktörlerin araştırılması. Uluslararası Yönetim Ikktisat ve İsletme Dergisi, 11(26), 151-169.

Field, A. (2005). Discovering statistics using SPSS (2nd edition b.). London: Sage.

Goldstein, H. A. ve Renault, C. S. (2004). Contributions of universities to regional economic development: A quasi-experimental approach. Regional Studies, 38(7), 733-746. 
Görmüş, A. Ş. (2009). Entelektüel sermaye ve insan kaynakları yönetiminin artan önemi. Afyon Kocatepe Üniversitesi I.İ.B.F. Dergisi, 11(1), 57-75.

Gürsakal, N. (2009). Çıkarımsal istatistik Minitab-SPSS uygulamalı. Bursa: Dora.

Gürsakal, N. (2012). Betimsel istatistik Minitab-SPSS uygulamall. Bursa: Dora.

Hanssen, T. ve Solvoll, G. (2015). The importance of university facilities for student satisfaction at a Norwegian University. Facilities, 33(13/14), 744-759.

Hummel, T. J. ve Lichtenberg, J. W. (2001). Predicting categories of improvement among counseling center clients. Seattle: The American Educational Research Association.

Isani, U. A. ve Virk, M. L. (2005). Higher education in Pakistan. Islamabad: National Book Foundation.

Kalayc1, Ş. (Ed.) (2010). SPSS uygulamalı çok değişkenli istatistik teknikleri. Ankara: Asil Yayın Dağıtım.

Kalfa, V. R. ve Karagül, N. (2014). Pamukkale Üniversitesi'nde okuyan ögrencilerin başarı durumlarını etkileyen faktörlerin lojistik regresyon analizi ile belirlenmesi. Isparta: 5th International Symposium on Econometrics, Operations Research and Statistics.

Karasar, N. (2016). Bilimsel araştırma yöntemi: Kavramlar, ilkeler ve yöntemler. Ankara: Nobel Akademik Yayıncılık.

Khan, M. A. ve Almas, A. (2013). A study of student satisfaction in the University of Agriculture Faisalabad. International Journal of Intelligent Technologies and Applied Statistics, 6(1), 21-34.

Kleinbaum, D. G. ve Klein, M. (2010). Ordinal logistic regression. D. G. Kleinburg ve M. Klein (Ed.), Logistic regression (s. 463-488) içinde. New York: Springer.

Korkmaz, M., Güney, S. ve Yiğiter, Ş. Y. (2012). The importance of logistic regression implementations in the Turkish livestock sector and logistic regression implementations/fields. Harran Journal of Agriculture and Food Sciences, 16(2), 25-36.

Korkulu, A. Y. ve Albez, A. (2018). Meslek yüksekokulu ögrencilerinin bölümlerinden memnuniyetleri üzerinde etkili olan faktörlerin belirlenmesi: Așkale MYO örneği. (s. 949-960). Edirne: IX. IBANESS.

Krejcie, R. ve Morgan, D. (1970). Determining sample size for research activities. Educational and Psychological Measurement, 30, 607-610.

Kurt, Ç. ve Erdem, A. (2012) Öğrenci başarısını etkileyen faktörlerin veri madenciliği yöntemleriyle incelenmesi. Politeknik Dergisi, 15(2), 111-116.

Larasati, A., DeYong, C. ve Slevitch, L. (2011). Comparing neural network and ordinal logistic regression to analyze attitude responses. Service Science, 3(4), 304312 .
Lee, G., Jolly, N., Kench, P. ve Gelonesi, B. (2000). Factors related to student satisfaction with university. 4th Pacific Rim-First Year in Higher Education Conference: Creating Futures for a New Millennium konferansinda sunulan bildiri, Brisbane, Australia. Erişim

Adresi: http://fyhe.com.au/past_papers/papers/JollyPaper.doc

Lipsitz, S. R., Fitzmaurice, G. M. ve Molenberghs, G. (1996). Goodness-of-fit tests for ordinal response regression models. Journal of the Royal Statistical Society, 45(2), 175-190.

McCullagh, P. (1980). Regression models for ordinal data. Journal of the Royal Statistical Society - Series B, 42(2), 109-142.

McCullagh, P. ve Nelder, J. A. (1989). Generalized linear models. London: Chapman and Hall.

Norusis, J. M. (2005). SPSS 14.0 advanced statistical procedures companion. www.norusis.com/pdf/ ASPC_v13.pdf. adresinden alındı (Erişim Tarihi: $15 / 03 / 2020)$

Nwakuya, M. T. ve Mmaduka, O. (2019). Ordered logistic regression on the mental health of undergraduate students. International Journal of Probability and Statistics, 8(1), 14-18.

O'Driscoll, F. (2012). What matters most: An exploratory multivariate study of satisfaction among first year hotel/hospitality management students. Quality Assurance in Education, 20(3), 237-258.

Osman, A. R., Saputra, R. S. ve Saha, J. (2017). Determinants of student satisfaction in the context of higher education: A complete structural equation modeling approach. British Journal of Marketing Studies, 5(6), 1-14.

Özdamar, K. (1997). Paket programlar ile istatistiksel veri analizi I: MINITAB, SPSS, SYSTAT. Eskişehir: Anadolu Üniversitesi Yayınları.

Özdamar, K. (1999). Paket programlar ile istatistiksel veri analizi - 1: SPSS - MINITAB. Eskişehir: Kaan Kitabevi.

Özdinç, D. (1999). Bankaların değerlendirilmesinde istatistiksel bir yaklaşım. Iktisat Işsletme ve Finans, $158,74-93$

Özer, H. ve Sarı, A. (2009). Kovaryans analizi modelleriyle üniversite öğrencilerinin başarılarını etkileyen faktörlerin belirlenmesi: Atatürk Üniversitesi İIBF öğrencileri için bir uygulama. Dokuz Eylül Üniversitesi İktisadi ve İdari Bilimler Fakültesi Dergisi, 24(2), 105-126.

Pulkstenis, E. ve Robinson, T. (2004). Goodness-of-fit tests for ordinal response regression models. Stat. Med., 23, 999-1014.

Schertzer, C. B. ve Schertzer, S. M. (2004). Student satisfaction and retention: A conceptual model. Journal of Marketing for Higher Education, 14(1), 7991. 
Şeker, R., Çınar, D. ve Özkaya, A. (2004). Çevresel faktörlerin üniversite ögrencilerinin başarl düzeyine etkileri. XIII. Ulusal Eğitim Bilimleri Kurultayı, İnönü Üniversitesi, Malatya, 6-9 Temmuz 2004.

Şerbetçi, A. ve Özçomak, M. S. (2013). Sıralı lojistik regresyon analizi ile istatistik ve ekonometri derslerinde başarıyı etkileyen faktörlerin belirlenmesi: Atatürk Üniversitesi İktisadi ve İdari Bilimler Fakültesi öğrencileri üzerine bir uygulama. Kahramanmaraş Sütçü İmam Üniversitesi Iktisadi ve İdari Bilimler Fakültesi Dergisi, 3(1), 89-110.

Stutler, D. ve Calvario, D. (1996). In alumni support, satisfaction matters. Fund Raising Management, 27(9), 12-14.

Sümbüloğlu, K. ve Akdağ, B. (2009). Ileri biyoistatistiksel yöntemler. Ankara: Hatiboğlu Basım ve Yayım.

Tessema, M., Ready, K. ve Malone, C. (2012). Effect of gender on college students' satisfaction and achievement: The case of a midsized midwestern public university. International Journal of Business and Social Science, 3(10), 1-11.

Thomas, E. H. ve Galambos, N. (2004). What satisfies students? Mining student-opinion data with regression and decision tree analysis. Research in Higher Education, 45, 251-269.

Tüzüntürk, S., Taşkın, Ç. ve Tuncel, C. (2015). Kıbrıs okuryazarlığının ve Kıbrıs sorunu algısının istatistiksel analizi: Türkiye'deki Y kuşağı örneği. Sakarya İktisat Dergisi, 4, 20-45.

Üçdoğruk, Ş., Akın, F. ve Emeç, H. (2001). Türkiye hanehalkı eğlence kültür harcamalarında Tobit modelinin kullanımı. Gazi Üniversitesi İktisadi ve İdari Bilimler Fakültesi Dergisi, 3(3), 13-25.

Umbach, P. ve Porter, S. (2002). How do academic departments impact student satisfaction? Understanding the contextual effects of departments. Research in Higher Education, 43(2), 209-234.

Valero, A. ve Reenen, J. V. (2019). The economic impact of universities: Evidence from across the globe. Economics of Education Review, 68, 53-67.

Walker, S. ve Duncan, D. (1967). Estimation of the probability of an event as a function of several independent variables. Biometrika, 54(1-2), 167-179.

Yakut, E., Gündüz, M. ve Demirci, A. (2015). İnsani kalkınmışlık düzeyinin sınıflandırma başarılarının karşılaştırılmasında sıralı lojistik regresyon analizi ve yapay sinir ağları yöntemlerinin kullanılması. Işletme Araştırmaları Dergisi, 7(4), 172-199.

Yüksel, C., Bilgen, İ. ve Kobal, H. (2018). Yükseköğretim kurumlarında memnuniyet kavrami: Kuramsal bir derleme. Insan ve Toplum Bilimleri Araştırmaları Dergisi, 7(3), 1582-1591. 
EK - 1. Etik Kurul Onayı

T.C.

ADNAN MENDERES Ü NIVERSITESI REKTÖRLÜĞ̈̈

SOSYAL VE BEȘERI BILINILER ARASTIRMAL.ARI

ETIK KURLLL

SAYI: $31906847050,04,04-08 / 06$

KONU: Başvurunuzun deg̃erlendirilmesi

AYDIN

$14 / 02 / 2020$

\author{
Sayın Dr. Ögr. Üyesi Engin C AKIR \\ Aydın Adnan Menderes Üniversitesi \\ Nazilli ilBBF, İsletme ABD. Öğretim Üyesi
}

Adnan Menderes Ûniversitesi Sosyal ve Beşeri Bilimler Arașturmalan Etik Kurulu'nun 14/02/2020 tarihinde yapilan olağan toplantısında çalıșmanızla ilgili alınan 03 nolu karar aşağıda sumulmuştur.

Bilgilerinize sunarum.

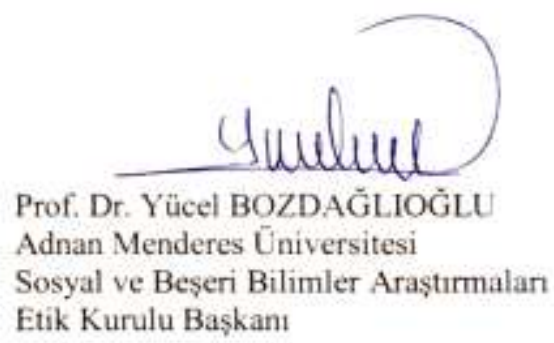

KARAR-

Protokol No

Sorumlu Yürütücü : Sayın Dr. Öğr. Üyesi Engin ÇAKIR

Aydın Adnan Menderes Üniversitesi

Nazilli iiBF, İşletme ABD. Ögretim Ûyesi.

Adnan Menderes Üniversitesi Sosyal ve Beșeri Bilimler Araștırmalan Etik Kurulu’nea 14/02/2020 tarihinde onay verilen; Aydın Adnan Menderes Üniversitesi Nazilli İBF. Işletme ABD. Dr. Öğrt. Üyesi Engin CAKIR' in yürütücūlügūnü yapmiş olduğu “Öğrencilerin Okudukları Bölümlerden Duydukları Memnuniveti Etkileven Faktörlerin Sıralı Lojistık Regresvon ile Belirlenmesi" konulu araștırma başvurusuna ait 10/02/2020 tarihli dilekçesi göruişüldü.

Cahıșmanın Etik Kurul Uygunluk Onayımı almasına oy birliği ile karar verilmiștir. 